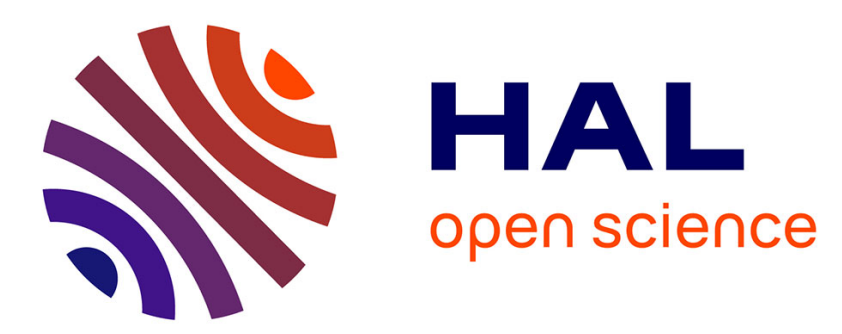

\title{
Role of glyphosate in the emergence of antimicrobial resistance in bacteria?
}

Didier Raoult, Linda Hadjadj, Sophie Alexandra Baron, Jean-Marc Rolain

\section{To cite this version:}

Didier Raoult, Linda Hadjadj, Sophie Alexandra Baron, Jean-Marc Rolain. Role of glyphosate in the emergence of antimicrobial resistance in bacteria?. Journal of Antimicrobial Chemotherapy, 2021, 76 (7), pp.1655-1657. 10.1093/jac/dkab102 . hal-03334121

\section{HAL Id: hal-03334121 \\ https://hal-amu.archives-ouvertes.fr/hal-03334121}

Submitted on 17 Sep 2021

HAL is a multi-disciplinary open access archive for the deposit and dissemination of scientific research documents, whether they are published or not. The documents may come from teaching and research institutions in France or abroad, or from public or private research centers.
L'archive ouverte pluridisciplinaire HAL, est destinée au dépôt et à la diffusion de documents scientifiques de niveau recherche, publiés ou non, émanant des établissements d'enseignement et de recherche français ou étrangers, des laboratoires publics ou privés. 


\title{
Role of glyphosate in the emergence of antimicrobial resistance in bacteria?
}

\author{
Didier Raoult ${ }^{1,2}$, Linda Hadjadj ${ }^{1,2}$, Sophie Alexandra Baron ${ }^{1,2}$ and Jean-Marc Rolain ${ }^{1,2 *}$ \\ ${ }^{1}$ Institut Hospitalo-universitaire Méditerranée Infection, Marseille, France; ${ }^{2}$ Aix Marseille Université, Institut de Recherche pour le \\ Développement (IRD), Assistance Publique-Hôpitaux de Marseille (APHM), Microbes Evolution Phylogénie et Infections (MEPHI), \\ Marseille, France \\ ${ }^{*}$ Corresponding author. E-mail: jean-marc.rolain@univ-amu.fr
}

Received 25 January 2021; accepted 2 March 2021

\begin{abstract}
There is a discrepancy between antibiotic use in medicine and agriculture in the intertropical zone and frequency of antibiotic resistance in clinical bacteria in these countries. We provide evidence that glyphosate (a herbicide but also an antibiotic drug) could be a possible driver of antibiotic resistance in countries where this herbicide is widely used because of modification of the microbial environment. Emergence of resistance in bacteria and fungi is correlated with glyphosate use in the world over the last 40 years.
\end{abstract}

For several years, we have been witnessing the emergence of MDR bacteria from the intertropical zone, although antibiotic use in humans remains quite low in this part of the world. This discrepancy between use of antibiotics in humans and frequency of antibiotic resistance is the subject of debate and several hypotheses are currently discussed in the scientific community. In India, China and Africa, resistance has increased considerably while clinical use of certain antibiotics has remained relatively low. ${ }^{1}$ The first hypothesis to explain this discrepancy highlighted that, while antibiotic use was low, their use was not controlled by antibiotic stewardship. The second hypothesis was the huge use of drugs in the farm industry; ${ }^{2}$ this can probably be accepted as an explanation for resistance to colistin ${ }^{3}$ and tetracyclines, but probably not for carbapenem antibiotics, which do not seem to have a disproportionate veterinary use. ${ }^{4}$ Conversely, imipenem resistance mediated by production of New Delhi metallo- $\beta$-lactamase (NDM) emerged in India, ${ }^{5}$ while recent work in Africa has shown that wild animals living in the city of Nairobi were carriers of MDR Escherichia coli, which cannot be explained by artificially increased consumption for agricultural reasons. ${ }^{6}$ In addition, recent work has shown that remote tribes living in Tanzania had MDR bacteria in the absence of significant exposure to antibiotics. ${ }^{7}$ In addition, we had the opportunity to identify an imipenem-resistant gene in lice collected in an extremely remote rural area of Sine Saloum in Senegal. ${ }^{8}$ All these data show that there is a discrepancy in the intertropical zone between a low level of antibiotic usage in humans and a high level of antibiotic resistance in bacteria isolated from different ecosystems. Antibiotic resistance is an ancient and natural phenomenon that has evolved because antibiotics are natural secondary metabolites secreted by microbes to survive and to fight in complex ecosystems before the use of antibiotics by humans. ${ }^{9}$ Hence, there are clearly other sources that may exert a selective pressure in the environment to explain the emergence of contemporary antimicrobial resistance in bacteria. ${ }^{4}$ In this respect, several new hypotheses have been proposed. The first is that there are bacteria in the intertropical zone that naturally secrete broad-spectrum $\beta$-lactam antibiotics, such as carbapenem antibiotics, because we know that several bacteria secrete such kinds of antibiotics including Streptomyces, Serratia or Erwinia, ${ }^{10}$ and selection may come from an ecosystem not linked to humans' usage of antibiotics. The second hypothesis is the role of glyphosate as a possible driver of antibiotic resistance in microorganisms because this compound has been widely used by humans in agriculture over the last 40 years. ${ }^{11}$ Glyphosate is a phosphonic acid widely used as a herbicide worldwide (and is also an antibiotic drug) and used in particular countries of the intertropical zone at doses that exceed all those possibly used in normal agriculture, but also in the cultivation of Genetically Modified Organisms (GMOs). ${ }^{11}$ The mode of action of glyphosate is the inhibition of the shikimate pathway, especially the enzyme 5-enolpyruvylshikimate-3-phosphate synthase (EPSPS); this enzyme is commonly found in certain bacteria and fungi, but is absent in mammals. ${ }^{12}$ In fact, GMOs have been modified to carry this EPSPS gene of bacterial origin for resistance to 


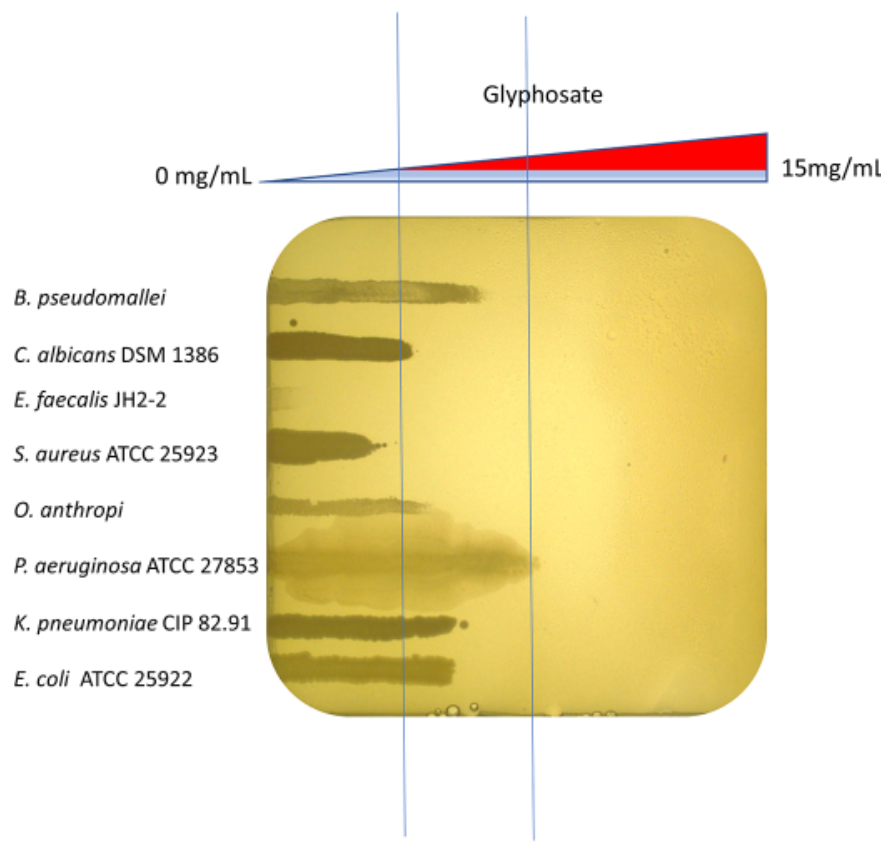

Figure 1. Growth of bacteria and fungi on an agar plate on a gradient of glyphosate. A double-layer sloping Luria-Bertani (Beckton Dickinson, Le Pont de Claix, France) glyphosate agar (Radikal green, Fitogal) with a gradient from 0 to $15 \mathrm{mg} / \mathrm{mL}$ was used for growth of bacteria and fungi. A microbial suspension of eight different strains including Burkholderia pseudomallei, Candida albicans DSM 1386, Enterococcus faecalis JH2-2, Staphylococcus aureus ATCC 25923, Ochrobactrum anthropi strain 9793, Pseudomonas aeruginosa ATCC 27853, Klebsiella pneumoniae CIP 82.91 and Escherichia coli ATCC 25922 calibrated at 0.5 MacFarland were inoculated on the agar plate using swabs. Microbial growth was observed after $48 \mathrm{~h}$ of incubation at $37^{\circ} \mathrm{C}$. This figure appears in colour in the online version of $J A C$ and in black and white in the print version of JAC.

glyphosate and thus glyphosate plays a role in the selection of plants carrying this resistance by only allowing GMOs to grow. Under these conditions, one can imagine quantities of glyphosate dumped in rice fields, for example, or in corn crops, which are probably the most widespread GMOs in the world, cultivated massively in the intertropical zone, particularly in Asia. In fact, glyphosate has a direct antibiotic effect on bacterial EPSPS like fosfomycin (another phosphonic acid used in humans as an antibiotic), which is well known since a patent has been taken by Monsanto on the antimicrobial activity of glyphosate against a wide range of bacteria, fungi and parasites that contain the EPSPS enzyme. ${ }^{13}$

It has been recently shown that there was a correlation between emergence of resistance in bacteria and fungi and glyphosate use in the world during the last 40 years. ${ }^{11}$ This is correlated with a huge amount of residue of glyphosate in the environment (soil, water), but also in plants. ${ }^{11}$ There is also an inducing or repressing effect of antibiotic resistance, which has been demonstrated in E. coli and Salmonella enterica. ${ }^{14}$ In E. coli, for example, the presence of glyphosate increases the level of quinolone resistance when bacteria are brought into contact with glyphosate at sublethal doses because of the overexpression of the $A c r A B$ efflux pump. ${ }^{14}$ Interestingly, there is also evidence that fosfomycin resistance in Gram-positive and Gram-negative bacteria from humans and animals has increased over the last 40 years and is higher in countries that widely used glyphosate, especially in China. ${ }^{15}$ In these conditions it is clear that we have the proof of concept that glyphosate, which is both a herbicide and an antibiotic, substantially modifies the microbial ecosystem, and that this modification may lead to changes in the susceptibility of the resident bacteria and selection of resistant bacteria in the environment that may further spread into clinical strains. ${ }^{11}$ For example, Ochrobactrum anthropi ${ }^{16}$ and Burkholderia pseudomallei ${ }^{17}$ are naturally resistant to glyphosate whose incidence has increased in the intertropical zone, particularly in Asia. ${ }^{18}$ In fact, many microorganisms could be selected by glyphosate because they can resist high concentrations of this compound, as depicted in Figure 1. We believe that it is essential to begin to rigorously evaluate the role of modification of the microbial environment by the use of glyphosate and in particular its role in the observed increase in antibiotic resistance of bacteria in countries that use few antibiotics in humans and in those that use glyphosate massively for agriculture. Further works are warranted to confirm this hypothesis.

\section{Funding}

This work was supported by the French Government under the 'Investments for the Future' programme managed by the National Agency for Research (ANR) and the IHU Mediterranee-Infection (reference 10IAHU-03), Marseille, France.

\section{Transparency declarations}

None to declare.

\section{References}

1 McEwen SA, Collignon PJ. Antimicrobial resistance: a one health perspective. Microbiol Spectr 2018; 6: 521-47.

2 Van Boeckel TP, Brower C, Gilbert M et al. Global trends in antimicrobial use in food animals. Proc Natl Acad Sci USA 2015; 112: 5649-54.

3 Olaitan AO, Dandachi I, Baron SA et al. Banning colistin in feed additives: a small step in the right direction. Lancet Infect Dis 2021; 21: 29-30.

4 Rolain JM. Food and human gut as reservoirs of transferable antibiotic resistance encoding genes. Front Microbiol 2013; 4: 173.

5 Kumarasamy KK, Toleman MA, Walsh TR et al. Emergence of a new antibiotic resistance mechanism in India, Pakistan, and the UK: a molecular, biological, and epidemiological study. Lancet Infect Dis 2010; 10: 597-602.

6 Hassell JM, Ward MJ, Muloi D et al. Clinically relevant antimicrobial resistance at the wildlife-livestock-human interface in Nairobi: an epidemiological study. Lancet Planet Health 2019; 3: e259-69.

7 Subbiah M, Caudell MA, Mair C et al. Antimicrobial resistant enteric bacteria are widely distributed amongst people, animals and the environment in Tanzania. Nat Commun 2020; 11: 228.

8 Kempf M, Rolain JM, Diatta G et al. Carbapenem resistance and Acinetobacter baumannii in senegal: the paradigm of a common phenomenon in natural reservoirs. PLoS One 2012; 7: e39495.

9 D'Costa VM, King CE, Kalan L et al. Antibiotic resistance is ancient. Nature 2011; 477: 457-61.

10 Coulthurst SJ, Barnard AML, Salmond GPC. Regulation and biosynthesis of carbapenem antibiotics in bacteria. Nat Rev Microbiol 2005; 3: 295-306. 
11 Van Bruggen AHC, He MM, Shin K et al. Environmental and health effects of the herbicide glyphosate. Sci Total Environ 2018; 616-617: 255-68.

12 Duke SO. The history and current status of glyphosate. Pest Manag Sci 2018; 74: 1027-34.

13 Wildwood W. Glyphosate formulations and their use for the inhibition of 5-enolpyruvylshikimate-3-phospate synthase. 2010.

14 Kurenbach B, Marjoshi D, Amábile-Cuevas CF et al. Sublethal exposure to commercial formulations of the herbicides dicamba, 2,4-dichlorophenoxyacetic acid, and glyphosate cause changes in antibiotic susceptibility in Escherichia coli and Salmonella enterica serovar Typhimurium. MBio 2015; 6: e00009-15.
15 Aghamali M, Sedighi M, Zahedi Bialvaei A et al. Fosfomycin: mechanisms and the increasing prevalence of resistance. J Med Microbiol 2019; 68: $11-25$.

16 Tian Y-S, Xiong A-S, Xu J et al. Isolation from Ochrobactrum anthropi of a novel class II 5-enopyruvylshikimate-3-phosphate synthase with high tolerance to glyphosate. Appl Environ Microbiol 2010; 76: 6001-5.

17 Peñaloza-Vazquez A, Mena GL, Herrera-Estrella L et al. Cloning and sequencing of the genes involved in glyphosate utilization by Pseudomonas pseudomallei. Appl Environ Microbiol 1995; 61: 538-43.

18 Gassiep I, Armstrong M, Norton R. Human Melioidosis. Clin Microbiol Rev 2020; 33: e00006-19. 